\title{
The Study of China Retail Business Development Strategy
}

\author{
Jing Sun \\ School of Business Management, Shenyang University \\ Shenyang 110041, China \\ E-mail: sunjing9819@yahoo.com.cn
}

Jingting Ma

School of Graduate, Shenyang University

Shenyang 110041, China

\begin{abstract}
After China joined the World Trade Organization (WTO), many retail investors from all over the world are developing quickly in China. They are expanding their market size and share, thus Chinese retailers are facing more severe competition. Chinese retailers need not only understand themselves as well as understanding their components so that Chinese retailing will continue to exist and develop in the acute competition environment
\end{abstract}

Keywords: Retail, Competition, Development strategy, Countermeasure

\section{Foreign capital Retail business's trend of development and characteristic}

1.1 The management strategy: The foreign capital Retail business constructs the trade integration management system in the industry, implements the global trade strategy.

These enterprises have the numerous subsidiary companies and stores in overseas, forms integrated and so on trade, sale, and information world management networks. In worldwide scale, the various subsidiary companies and branches under base companies unified command implements the unification supply, the unification allocation, the unification sale, the unification settles accounts. Facing the world market, they consider the whole world business strategy, thus causes the enterprise to obtain the greatest income.

1.2 The investment seize: the expansion order, proceeds in an orderly way, invests from the dispersion to the formalization investment management.

The centralism investment and the large-scale management is the foreign capital retail business's investment strategy in order to seize the international market. Demonstrated according to the material that the transnational retail business such as Wal-Mart, Carrefour, and Metro and so on direct investment in Beijing, Shanghai, and Shenzhen and so on, the highest investment cost reaches as high as more than 300,000,000 US dollars, the investment scale is bigger than existing commercial facilities in China.

1.3 The management position strategy: Every successful foreign capital Retail business in China, majority chooses the global most growing main force retail sales business strategy, grabbing the most growth prospect market domain.

They has adopted direct spanning traditional food supermarket and the standard food supermarket pattern in the supermarket management position, direct set up large-scale synthesis supermarket and warehousing type supermarket.

1.4 The technical strategy: The foreign capital retail business manages enterprise massively using the present information technology.

Wal-Mart's information system is the most advanced commercial information technology system, it has main feature including more invests, the function entire, the speed to be quick, intellectualized and global networking. Wal-Mart invested the large amount fund in the information technology; there are more than 2000 engineers who were responsible for the software design special in the company. At present, between Wal-Mart China Corporation and the American Corporation's relation is transmits through the satellite, thus caused China's chain store to integrate in truly its worldwide scale chain-like network, the competitive advantage was obvious. Metro Corporation utilized the computer technology to consummate a set science executive program from the purchase to the sales; the computer control system has grasped the commodity purchase, sales, storage process, thus it might control the inventory in the most reasonable 
level. When commodity quantity is lower than the security reserves, the computer can produce the order form automatically, issues the ordering notice to the supplier, thus it has guaranteed the commodity continually supply and the low cost management. The computer reflect detailed the sales situation, not only has supplied sales quantity and each kind of information, and has also recorded each kind of customer purchase frequency and the shopping structure, thus may reflect accurately the customer demand tendency and the development trend, enable Metro Corporation to adjust promptly the goods structure and the management strategy.

\section{Foreign capital retail business's trend of development to China retail business's impact and challenge}

\subsection{The foreign capital Retail business implements the formalization, the chain-like management, seizes China} consumer market by the low price strategy, and forms the absolute cost advantage.

The foreign capital Retail business is mostly big enterprise that has the varying degree monopolistic position, the management scale is bigger, and some large-scale transnational Retail business's global annually sales volume even surpasses many national's gross industrial output value in the world. For example Wal-Mart Corporation's total sales were 193.2 billion U.S. dollars in 2000 , the profit are 6.3 billion U.S. dollars. The economies of scale bring the scale benefit, not only causes the direct production cost of operation to reduce, moreover in aspects and so on allocation, retailing, has the absolute comparison cost advantage. Although the Wal-Mart retail price is lower than other supermarkets, what adopts is the low price sale strategy, but the sales ratio of margin actually achieves $21 \%$, after the tax, the net profit achieves 3.3\%.it is more higher than Chinese Retail business greatly. But China's Retail business, for example Beijing's Wang-fu-Jing department store, the Wuhan department store and so on, compares with the overseas Retail business, also can only be the Small business.

\subsection{The foreign capital Retail business implements the modern goods allocation, establishes the manufacturer, the supplier and the retail merchant cooperation pattern, forces China Retail business to establish the new production and marketing relations.}

Because China Retail business forms the unique market superiority under the buyers' market condition, forces the supplier has arrogated to oneself the commodity all operational risk when sales goods. But under the market economy condition, the enterprise takes an economic entity, its operational risk cost includes the enterprise product cost inevitably, and transforms to the commodity price, directly causes the commodity price to stay at a high level for a long time, dull sale. Thus, on the one hand causes the consumer welfare surplus reduction, on the other hand causes the production and marketing contradictory prominent, causes the enterprise to manage difficultly. From looking the foreign capital Retail business may discover that the foreign merchant in the commodity purchase is generally take the market demand as the choice standard, through the investment, the share-holding, the holding, sells outright and so on monopoly, establishes the more fixed upstream supplier and the goods supply base, guarantees the source of goods quality fineness, the price inexpensive and the variety quantity sufficiency. In the allocation aspect, the corporation has to adopt the "one-stop" work style, implements the unification allocation. For example German Metro Corporation investment constructs huge and the stable vegetables Support base in the Shanghai suburb. US's Wal-Mart Corporation direct or indirect the merchandise exports total amount which purchased in China reaches as high as 10 billion U.S. dollars annually in recent years, now the commodity headquarters of allocates and dispatches has been shifted to the Chinese Shenzhen. The modernized supply of commodities allocation chain pattern brings the international economy benefit which exceeds the quota.

2.3 The foreign capital Retail business implements the localization strategy in the investment management process, forms competing commercial talented person's competition aspect with China retail business

After China joins WTO, the foreign capital Retail business does not hesitate the price to attract the Chinese commercial domain outstanding talent. However, looked from the Chinese retail trade's operating condition that human resources' quality level is also very low, but also exists that the talented person does not be taken seriously and the waste phenomenon, these have restricted China Retail business's innovation and the reform seriously.

\section{Facing the foreign capital Retail business's challenge, the countermeasure which China Retail business develops}

\subsection{Establishes and improves Chinese domestic trade protection policy and the market access mechanism}

China has already joined WTO, must fulfill the WTO basic maxim completely, but this was not equal to that said joined WTO, China's retail market was the perfect competitive market, did not need the government to implement essential intervention and control. In fact, in does not violate the WTO rule under the premise, some country which joined WTO early has to formulate laws and regulations and the policy that conformed to oneself national condition, avoids harming oneself country excessively economic interest,. For example U.S. government in order to control the imported goods quantity, protects the domestic manufacturer benefit, implements the customs import quota to the partial products. Therefore, under the WTO criterion, China should also formulate policies and regulations that conform to the international convention to protect the domestic Retail business. 
3.1.1 Formulates counter-dumping and antimonopoly law. When some transnational Retail business relies on their abundant fund, the advanced technology and the inexpensive price or implements the low price dumping strategy to some commodity's production and retailing implementation monopoly, may rest on this law to limit.

\subsubsection{Implement the green barrier protection.}

The green barrier protection refers to one kind to protect the limited resources and the public health name, through formulates a series of harsh environmental standard, to limit the project and the imported goods which the foreign capital Retail business invest.

3.1.3 Implement technology trade barrier. The technology trade barrier refers to one tariff barrier measure which the commodity import and export country in view of foreign commodity quality, specification, nutritional value, use and explanation, habitat proof, packing trademark and so on, formulation strict technologies, health quarantine. The WTO member nation government establishes the technical barrier generally, reduces the imported product competitive power. Therefore, China may also take the international advanced technical standard management commodity import, protects the domestic consumption market.

\subsection{Implementation chain-like managements and improve China Retail business's market survivability, the competition strength and the develop power as soon as possible.}

According to the commercial law of development, the sole shop's sales growth has certain limit, if the enterprise wants to obtain market space in the marketability degree high commercial domain, must transform through organization, implementation expansion strategy, and realizes the benefit growth. Setting up the chain store is an effective way. In fact, in the overseas, many big Retail businesses dependence chain-like way forms the scale benefit gradually. American Wal-Mart Corporation increased the approximately 30 billion U.S. dollars sales volumes in 2000, comes from the annexation and the new start shop completely. Is opposite says in the Chinese market, 8 Wal-Mart retails supermarket sales volume to be possible to reach 3 billion U.S. dollars to 4 billion U.S. dollars annually. Other international retail merchants, for example Carrefour, Metro, the chain-like supermarket which opens in China sells well mostly. Therefore, the chain-like management is most efficient paths one that breaks China Retail business tradition business model, promotes China Retail business's market survivability, the competition strength and develop power. The chain-like commercial essential characteristic requests its management and operation must realize standardization and scientific. In view of Chinese chain-like commercial management and operation present situation, the enterprise should strengthen standardized management from the following several aspects.

3.2.1 Implements headquarter global administration, should achieve unification enterprise recognition system, unification inventory, unification calculation, unification fixed price and so on.

3.2.2 Implements retail operation and management process standardized. The Developed country's Chain-like Company managed process management already to form high standardization, simplification, centralization and scientific style, used the computer management information system to aspect inventory, sale, memory, fund, finance data and the feedback information carries on processing promptly, at the right moment, accurate, highly effective, frugal cost. China retail chain enterprise must take standard management and management tool modernization fully, can adapt business management modernization request.

3.2.3 Takes marketing strategy and marketing method unity. The chain-like enterprise must take the target market localization, the commodity localization and the service localization, takes the enterprise overall strategy, from commodity equipment, service, shop site choice, price arrives and promotion, should have one whole complete strategy.

3.2.4 Unifies training, improves the enterprise staff's overall quality. Because chain-like enterprise's all branch stores should defer to the unification job specification to achieve the unification service standard, therefore, unification training is the global administration main part.

3.2.5 Implements the allocation center modernization. The allocation center is the chain store's distribution organization, its major function is that undertakes various chain stores inventory, stock, processing, transportation, to deliver goods and so on duties. The allocation center may communicate the headquarter and the branch shop, reduced circulated link through the centralism allocation and reduced the transaction cost, thus raised the commodity socialized level, has realized economies of scale, expanded selling profits. Establishes highly effective allocation center, may reduce purchasing cost, reduces storage expense, saves cartage expense, reduces selling costs, maximum limit raises the chain-like enterprise's economic efficiency.

3.2.6 Establishes scientific organizations and the chain-like network system. In the chain-like management process, gains the information to manage success or failure of the chain-like enterprise to be important. Therefore, China's chain-like retail business must speed up construct own message center, strengthens facility of communication network, cash register, bar code developments and application, by prompt, unimpeded information flow guarantee commercial interchange and distribution smoothness, accomplishes chain-like management and operation modernization diligently. 


\subsection{Implements management adjustment, multiplex development}

3.3.1 Adjusts the target audience. Must unify own market historical and other factor to choice target client.

3.3.2 Adjusts the service function, by high-quality service win customers. From sole shopping function to entertainment, leisure, traveling, culture, dining and so on multi-purpose transformations.

3.3.3 Investment in the high tech, the infrastructure or other professions, forms one industry primarily, diversified management patterns.

\subsection{Implement customer loyal strategy, expands the market share, enhances the competitive advantage.}

The customer loyal strategy's core is that maintains the customer, enhances customer's loyalty. Raises the customer loyalty way and the measure includes:

3.4.1 Maintains the long-term close relationship with the customer. Establishes the customer data information bank, is the foundation of maintains for a long time with the customer contacting. The customer data information bank is a collection saves and analyzes with the enterprise customer's related each kind of information management system, the data information is obtained through market survey, may also through selling or the order register, the customer sues record and so on record to obtain. Each kind of information data should defer to the classified structure order memory which designs specially, like this may enhance analyzes and applies the customer information efficiency. At the same time, also progressive improvement and enhances the database information quality. The customer data information not only may help the enterprise to understand customer's consumer demand, by chance with the buying habit and so on important information, moreover may accord to information data which the database information provides, uses ways that provides product information, letter, telephone, visiting and so on regularly to strengthen with customer's communication, stimulates customer's redundant presence and redundant purchase.

3.4.2 Regards as the customer service's cost to the value investment. Provides satisfaction for the customer service usually spend certain cost, some enterprises regard as it to bear. In fact, provides satisfies service cost, is one item invests very valuably.

3.4.3 Regards as the enterprise staffs to the first essential factor. If enterprise want to enhance customer's loyalty, detains the customer, the key factor is enterprise's staff, especially directly the sales personals who contacts with the customer. But the staff treats customer's manner, is decided the enterprise treats staff's manner. If the enterprise respects the staff, kindly treats the staff, then the staff will also treat the customer by the similar way.

\section{References}

Ansoff. (1998). Corporate Strategy. New York: McGraw-Hill.

Han, Su \& Miao, Zhongying. (2004). Chain-like Management and Operation. Harbin Industry University Publishing House.

He, Rong \& Gao, Qian. (2007). Strategic Trade Policy In China's Suitable Condition Analysis. Foreign Trade Practice, Vol. 8 .

Rumelt, Schendel \& Teece. (1994). Fundamental Issues in Strategy. Harvard Business School Press.

Sun, Jing. (2004). Chinese Retailing Enterprise Countermeasures When Facing Foreign Capital Business Challenge. Economic Journal, Vol. 5.

Zhang, Haiyan. (2002). Chain-like Enterprise's Allocation Management. Chinese Commodity Publishing House. 